\title{
ECONOMIC VOTING IN BRAZILIAN PRESIDENTIAL ELECTIONS: EVIDENCE WITH PANEL DATA FROM MUNICIPALITIES IN SÃO PAULO
}

\author{
Voto econômico nas eleições presidenciais brasileiras: evidências \\ com dados em painel de municípios de São Paulo
}

Ivan Filipe de Almeida Lopes Fernandes*

Gustavo Andrey de Almeida Lopes Fernandes**

\section{ABSTRACT}

This paper uses a new data panel of 625 Brazilian municipalities over 5 election years to analyze the influence of the local level economic performance on the proportion of votes obtained by the incumbent in national elections. We examine municipalities from the State of São Paulo, the most populous Brazilian state, using fixed-effects and random- effects models. The results suggest that the performance of the local economy is relevant in the national elections. Apart from that, the results also suggest that the mayors play an important role in the national elections when it comes to transfer votes that are favorable to the coalition in power and that the richest municipalities tend to be more opposition prone.

Keywords: Elections. Voting behavior. Brazil.

\section{RESUMO}

Este artigo utiliza um novo painel de dados de 625 municípios brasileiros em 5 anos eleitorais para analisar a influência do desempenho econômico no nível local na proporção de votos obtidos pelo candidato incumbente nas eleições nacionais. Examinamos municípios do estado de São Paulo, o mais populoso estado brasileiro, usando modelos de efeitos fixos e aleatórios. Os resultados sugerem que o desempenho da economia local é relevante nas eleições nacionais. Além disso, os resultados também indicam que os prefeitos desempenham um papel importante nas eleições nacionais ao transferir votos favoráveis à coalizão no poder, assim como os municípios mais ricos tendem a ser local mais propenso a um voto de oposição.

Palavras-chave: Eleições. Comportamento eleitoral. Brasil.

\footnotetext{
* Profesor of Public Policy of the Federal University of ABC (PGPP/UFABC). Ph.D. in Political Science by Universidade de São Paulo (USP). Email: ivan.fernandes@ufabc.edu.br. ORCID: 0000-0002-4236-4393

** Profesor of the School of Administration of Fundação Getúlio Vargas (EAESP/FGV). Ph.D. in Economy by Universidade de São Paulo (USP). Email: gustavo.fernandes@fgv.br. ORCID: 0000-0001-8281-390X
} 


\section{INTRODUCTION}

T

his paper analyzes the relation between the local level of economic growth and the proportion of votes obtained by the presidential incumbent. The literature in the area has different conceptual definitions for economic voting - it can mean votes for the chief executive, government, cabinet or coalition, opposition, parties or volatility across elections (DUCH; STEVENSON, 2008). Here, we define economic voting as the vote choice for the reelection of president or for the designed candidate for succession. We also investigate the main municipal public expenditures that have an electoral impact on the incumbent votes and how these relations are affected by the political alignment between the president and mayors. More important than controlling for confounding factors, we want to understand how the municipality and mayors affect the propensity of incumbents receiving votes.

The municipality is the most local political administrative unit that has elections in Brazil and it is administered by a single mayor and a municipal council, and normally, mayors are the main representatives of higher level governments (gubernators and presidents) at the local level. Besides, analyses of Brazilian presidential elections are of special interest per se, even though we are only analyzing presidential elections in municipalities in the State of São Paulo's. Since the election of President Luiz Inacio Lula da Silva, the determinants of voting for incumbents in Brazil have been exhaustively discussed (HUNTER; POWER, 2007; NICOLAU; PEIXOTO, 2007; SINGER, 2009, 2012; ZUCCO, 2008).

While the analysis of Brazilian elections per se is of great importance, there is an additional factor of relevance in this paper, due to the relative absence of studies about the impact of local level variables in national elections. The main hypothesis is based on the economic voting theory, which suggests that incumbents have more chances of being re-elected, or of ensuring the election of their successor, when the economy is going through a favorable period (ANDERSON; MORGAN, 2011; DUCH; STEVENSON; 2008).

As indicated by Fernandes and Fernandes (2017), local economic factors tend to be perceived by voters in a more intense way than the growth of the economy as a whole. This is a real phenomenon in the Brazilian experience due to its large territory and the size of the population, where the huge distances make economic expansion a phenomenon that is necessarily local, even if we take into account only the votes in São Paulo, which is the most populous state, with 43 million people - the same as Argentina - and whose territory is larger than the United Kingdom. For example, the growth of an industrial cluster in the Brazilian Midwest may be the result of the closure of industrial plants in some areas of Sao Paulo. At the state level, the aggregate impact can be positive or negative, but in a disaggregated way, these are very different local economic experiences.

Therefore, we intend to contribute to this emerging literature introducing a new dataset to analyze whether local level economic and expenditure variables are determinants of support for the incumbent candidate. We analyze a sample of 625 municipalities in the state of São Paulo, the most populous Brazilian state, using panel data taken from the presidential elections of 1994, 1998, 2002, 2006, and 2010.

We bear in mind the fact that in our analysis we are taking into account the economic effects that most closely impact the voter's life. In doing so, we examine whether the 
economic effects that are closest to the daily life of the voters are important when it comes to defining their broader electoral preference in the national election. We use data of the municipal growth in energy consumption per capita as a measure of economic growth in order to test the hypothesis that voters tend to reward the incumbent party that had a good economic performance. We prefer to use energy consumption as a proxy of the real economy scenario because we have more reliable data on energy than on municipal Gross Domestic Product (GDP).

The article is divided in six sections, including this one. In the next section we present the literature about the determinants of the vote and succinctly present our theoretical framework. Also, we look at some of the main contributions that discuss voting determinants in Brazil. The third section describes the panel data methodology. In the fourth, we present our data. The econometric evidence found is the object of analysis in the fifth section, while in the sixth, and last, section we present our main conclusions.

\section{DETERMINANTS OF THE VOTE}

Attempts to explain how and why individuals vote have encouraged a robust research field that seeks to understand the motivation of the vote throughout the democratic world. There are three main schools of analysis of the electoral behavior: the sociological, psycho-sociological and economic. The sociological school started with studies carried out by Lazarsfeld, Berelson and Gaudet (1944) and Berelson, Lazarsfeld and MacPhee. (1954) that had found that few voters changed their preference during campaigns. This relative absence of change was due to some voter's structural characteristics: socio-economic position, religion and an urban-rural dichotomy.

This research program was criticized by Campbell et al., (1960) because it did not capture time variation in voter preferences. Instead, they proposed a socio-psychological analysis that, without denying the importance of macro-factors, showed the existence of individual intervening factors which better explained the voting decision, paying more attention to voter attitudes than to permanent social characteristics. Campbell et al. , (1960) emphasize how the affective ties of voters with regard to the parties influence the voting decision. The main empirical finding was that the stability of party identification, as changes in candidates or political platforms had little impact on the vote choice (PIMENTEL JR, 2007).

\subsection{THE ECONOMIC VOTING THEORY}

The economic school analyzes the behavior of voters from the point of view of the rational choice theory. Downs (1957) introduced the notion that individuals make vote choices based on their comparisons of expected utilities for each of the competing parties; here the citizens behave as consumers in a political market situation. Voters maximize their satisfaction having in mind government action and the parties achieve satisfaction from their electoral success. The interest calculation of the voter is carried out in accordance with the expected utility differential between the parties based on what the government in power 
offers in comparison with what would be obtained if the opposition were there. Fair (1978) provided a formal statement of how economic performance enters the voter utility.

Fiorina (1981) updates the argument analyzing how voters act rationally when facing scarcity of information. Fiorina's main argument is that voters, regardless of their degree of information, are sensitive to the impact of government activities for improvements in their well-being and use it as a guide for their vote. Thus, future expectations are, for most of the voters, simple extrapolations from current trends. The model is the workhorse of voting choice due to the fact that it demands very little from the average voter, as it does not require a high level of political sophistication for vote choice.

A key assumption lies in the understanding that the government has direct influence on the country's economic performance, leaving aside other factors that may have an impact on it, and that economic factors play an important role in electoral behavior. Therefore, an improvement in economic conditions increases the probability of a vote for the party that is perceived as responsible for the change. Also, better economic performance tends to indicate an administrative capacity of the party in power, in addition to positively affecting the votes of those who do not identify with any party (VIRMANI, 2004; ANDERSON; MORGAN, 2011).

The economic voting theory also suggests that the retrospective vote, based on economic results, allows voters to demand a degree of responsiveness from their elected politicians in managing the economy. Indeed, the mechanisms that connect the economic performance with the voting behavior can be a sanctioning process for bad economic performance (KRAMER, 1971; FAIR, 1978, 1996a, 1996b) or the use of past economic outcomes as informational clues to assess how competing potential parties might perform in the future (DOWNS, 1957; STIGLER, 1973).

Powell and Whitten (1993) demonstrated that sanction models of economic voting should explain variations in sanctioning behavior in terms differences in the clarity of incumbents' economic responsibilities. At those cases where there is no clarity of who is the main political agent in charge for economic policy, and consequently the country's economic performance, the effects of economic variables on election results should be minor or even completely absent. In other words, less or no political dynamic between economic performance and electoral support to the incumbent

Duch and Stevenson (2008) carried out an important study involving 18 democracies and showed that there is a significant relationship between economic perception and voting choice, above all in systems that concentrate the political decision power. They organized the literature around three important themes: the sanction and selection models and the context of voting (the strategic setting of economic decision making).

The sanction model requires that voters have retrospective information of the macroeconomy and that they punish/reward incumbents in a fashion that credibly signals to candidates the electoral costs of shirking and rent seeking. More important than rewarding good performance is to punish poor economic performance as a way to establish a threshold performance level that prevents the incumbent from shirking her responsibilities.

The selection model is future oriented and entails that voters choose the most competent candidates, using information about past economic outcomes to assess the future 
competencies of competing candidates. As information about the candidates' competence plays a crucial role in vote choice and governments differ in their competence, the economic outcomes are then important because they provide clues about it (CUKIERMAN; MELTZER, 1989),

Finally, the context is given by economic and political institutions and structures that can alter the effects of economic growth on the voting behavior of citizens, as they alter how economic policy decisions can really shape and impact the economic situation of the country. The more dispersed the economic policy decision making, for example, independent central bank or open economy countries, the less pronounced the economic voting effect.

Duch and Stevenson (2008) analyze this variation using 163 election surveys on western countries, estimating a different measure of economic voting for each party and analyzing the variation of the estimates across two decades and eighteen countries. They show that the proportion of decisions affecting economic outcomes taken by non-electorally accountable decision-makers declines the overall effect of growth on the election result. Also, the more dispersed the power after election results, meaning widely shared decision making power, the smaller the economic voting effect.

\subsection{LOCAL LEVEL ECONOMIC VOTING}

One of the main contributions of our research is that most of the studies on economic voting focus on data on regional or national levels and not on municipal or local data. In addition, most of these studies that look for local variables are concerned with the effects of fiscal manipulation or performance and not with economic performance. Sakurai and Menezes (2008) used panel data from more than 2,000 Brazilian municipalities over 13 years and showed the positive influence of public expenditures on the probability of mayors' reelection. Veiga and Veiga (2007) show that increases in investment expenditures and changes in the composition of spending favoring visible items are positively associated with vote percentages of incumbent mayors seeking re-election using data of all Portuguese mainland municipalities. Brender (2003), on the other hand, finds evidence that the fiscal performance of mayors positively impact their chances of re-election only in some of the Israeli local elections. Finally, Drazen and Eslava's (2010) is the unique study of electoral manipulation of municipal expenditures that includes GDP growth as one of the control variables and they find that it has a positive coefficient in most regressions using data from all Colombian municipalities; however, they do not include measures of local economic performance, instead, they just use national economic variables.

In sum, to the best of our knowledge, there are almost no studies that test the effect of the municipal economic performance on national elections. The only exceptions are the studies made by Pattie and Johnston (2001), Martins and Veiga (2013), Oliver and $\mathrm{Ha}$ (2007), and Elinder (2010). Pattie and Johnston (2001) showed the importance of the local economy in understanding voters' electoral behavior in the general elections of 1997 in the United Kingdom. Even though they had used individual level data, they found that local economic prosperity play a greater role in vote choice than both the improvement in the individuals' own economic well-being as well as the perception of changes in national economic prosperity. 
Martins and Veiga (2013) find a positive relation between the effects of national and local economic performance on the percentage of votes obtained by the party of the incumbent mayor in Portugal. Oliver and $\mathrm{Ha}$ (2007), using survey data of over 1,400 voters in 30 different US suburban communities concluded that better local economic conditions or local government performance is positively related with incumbent support. Finally, Elinder (2010) found that local economic conditions - economic growth and unemployment - affect the electoral performance of candidates in local counties in Sweden.

\subsection{VOTING DETERMINANTS IN BRAZIL}

Throughout the last decades various studies focused on the Brazilian electoral behavior. Simão (1956) analyzed the vote of the working classes in São Paulo in the 1940s and showed that there was a relationship between the proportion of workers within the city districts and the proportion of votes for the main left parties: the PCB (the Brazilian Communist Party) and the PTB (the Brazilian Labor Party). Simão also observed that the PCB voters were qualified industrial workers who had been living in the capital for a long time, while the PTB voters were largely migrants from rural areas with poor qualifications.

Ferreira (1960; 1962) analyzed the correspondence between socio-economic position and the party vote in the state of São Paulo, showing that voters from highly industrialized regions tended to vote for labor reform parties, while the less industrialized regions voted for traditional conservative parties. Using survey data, Soares (1965) found a correlation between the socio-economic situation and the presidential vote in the 1960 elections.

Cintra (1968) observed that political parties were relevant players in the Brazilian political scenario and showed that there was a correlation between votes of non-manual workers for the UDN (the National Democratic Union) and of manual occupation workers for the PTB. Along the same lines, Lamonier (1980) observed that around $70 \%$ of the electorate of São Paulo identified with a party, a very high number and comparable to the consolidated democracies of the time. Similar findings were found by Reis (1978) and Fleisher (1981).

However, with the end of the two-party politics of the military regime and the expansion of the democratic multiparty system in the 1980s, these high levels of party identification disappeared (BALBACHEVSKY, 1992; SINGER, 1999). As a result, studies on voting behavior in Brazil started to look for other determinants. Castro (1994) observed that, given the little sophistication of voters, most of them ended up voting for personalities and not parties. They argued that the results do not contradict the rationality assumption because popular and less sophisticated votes were being cast for those that presented themselves as 'defenders' of the popular interests. On the other side of the knowledge continuum, Kinzo (2005) and Carreirão and Kinzo (2004) showed that a significant part of the electorate that identified with a party was connected due to their level of education. Carreirão (2002) observed that an expressive component in the vote in Brazilian presidential elections was the retrospective vote, which was anchored in an assessment of the overall performance of the government in power, based mainly on the country's economic situation. 
Simoni (2017) proposes that since the 2006 elections there have been two great debates about Brazilian presidential elections. First, the re-election of Lula is considered as a moment in which a regional electoral realignment occurred. The electoral bases of the then president and leader of the PT (the Workers' Party) would have undergone an important inversion (HUNTER; POWER, 2007; NICOLAU; PEIXOTO, 2007). The PT and Lula would have lost strength at their old electoral base in the metropolises of the South and Southeast and began to receive support in the small municipalities of the North and Northeast (HOLZHACKER; BABALCHEVSKY, 2007; SINGER, 2012; ZUCCO; POWER, 2013). An analogous realignment occurred at the individual level. Less educated and poorer voters, who once were averse to the PT, became the core of Lula's electoral base from 2006 onwards. The literature is methodologically heterogeneous using individual, municipal and state level data.

The second proposition is that one of the main determinants of the presidential realignment, perhaps the most important one, was the expansion of the federal conditional cash transfer program, the Programa Bolsa-Família (PBF) (ZUCCO; POWER, 2013). The literature debates its electoral impact both at the individual and local economic levels. Renno and Cabello (2010) have found evidence that the highest electoral gain of Lula's 2006 reelection was in those regions that receive most of the PBF resources.

Hunter and Power (2007) have a very critical view of the regional realignment. They observe that the realignment was produced by a political usage of social policy. Nothing more than the "old history of using the government to build clientelistic support" (HUNTER; POWER, 2007, p. 9). In this direction, Zucco (2013) found a similar effect of similar conditional cash transfers programs promoted by Fernando Henrique Cardoso's government on the votes of the PSDB (the Brazilian Social Democracy Party) in 2002 - the Programa Bolsa Escola and Bolsa Alimentação.

Soares and Terron (2008) also show that most of the municipal votes for the PT from 2006 onwards have come from small and poor cities in the Northeast. On the other hand, Simoni (2017) shows with both individual level and local aggregated data that there was no realignment on the 2006 presidential elections and that the changes perceived by the media and the literature at large are just a reflection of the electoral behavior of swing-voters and not the realignment of any electoral base. Besides that, the PBF had improved the electoral performance of the PT with more impact in the Southeast than in the Northeast. Limongi and Guarnieri $(2014 ; 2015)$, using aggregated data, have also proposed that the realignment was less relevant, highlighting the importance of a long-term vision of the electoral fluctuation in Brazilian presidential elections and also emphasizing the stronger effects of the PBF in the Southeast than in the Northeast.

Others researchers have found evidence that the electoral alignments of 2006 were maintained during the elections of 2010 and 2014 (MARZAGÃO, 2013; PEREIRA et al., 2015; MAGALHÃES; SILVA; DIAS, 2015). They found evidence that the municipalities that voted for the PT in 2010 were the ones that had voted in the PT in 2006.

Another possible interpretation for the results of 2006 onwards was put by Ribeiro (2014), Canêdo-Pinheiro (2015) and Zucco (2008; 2010). They have argued that the results are driven by a manifestation of the Brazilian "governism". In other words, the 
tendency of poor municipalities which are dependent on the public sector, to always support the incumbent, regardless of the party in charge ${ }^{1}$.

\section{METHODOLOGY}

Given the nature of the research object, we will analyze the effects of the electoral performance on the proportion of votes obtained by the incumbent in municipalities in the state of São Paulo using a panel data framework. According to Hsiao (1986) and Cameron and Travedi (2005) panel models offer a series of advantages over cross-section models because they allow control over the idiosyncratic heterogeneity present in each individual in the sample and they also increase estimation accuracy and precision.

In this manner, three different estimates will be carried out, to check the effect of the variables of interest. First, we estimate using a pooled regression model (POLS). Then we use the random effects model (RE) and finally the fixed effects model (FE), which allows consistent estimation of the coefficients of interest even in the presence of unobservable idiosyncratic heterogeneity correlated with other regressors. We then check which model is the most suitable for our data, maximizing efficiency and the consistency of the coefficients.

In the basic POLS model, the estimator considers all the information as cross-section units, ignoring the temporal aspect of the data. The random and fixed effects models take into consideration the presence of idiosyncratic heterogeneity, which are considered to be part of the intercept in the former and of the error in the latter. Both require a strict exogeneity assumption. This implies that the error term must be uncorrelated with any of the regressors in any period of time. In other words, both assume that the error has a conditional mean of zero in past, present and future values of the regressors (CAMERON; TRAVEDI, 2005). The random effects model deals with the unobservable idiosyncratic heterogeneity correlated (ci) as a random variable that is distributed regardless of the regressors and with homoscedastic variance. The random effects model will be estimated by feasible generalized least squares (FGLS) due to the fact that the variance-covariance matrix is unknown.

Random Effects Model:

$$
Y_{i t}=\alpha+X_{i t} \beta+v_{i t}=\alpha+X_{i t} \beta+\left(c_{i}+\varepsilon_{i t}\right)
$$

where vit is the compound error given by $c_{i}+\varepsilon_{i t}$

$$
\mathrm{E}\left(\boldsymbol{v}_{\boldsymbol{i t}} / \boldsymbol{X}_{\boldsymbol{i s}}\right)=0 ; \forall \mathrm{t} \neq \mathrm{s} ; \boldsymbol{v}_{i \boldsymbol{t}} \sim \mathrm{N}\left(0, \sigma^{2}\right)
$$

Finally, the fixed effects model considers different intercepts for individuals, assuming that the inclinations and variance are constant. The unobservable idiosyncratic heterogeneity, $\mathrm{ci}$, is no longer dealt as a random variable but as a parameter to be estimated.

1. This result is confirmed once again in our analysis - see section 5 . 
So, unlike random effects, the fixed effects model allows consistent estimation even in the presence of $c i$ correlated with the regressors. Estimation of the fixed effects requires the strict exogeneity assumption. To estimate the fixed effects model, we use within transformation techniques, since it is more efficient when $t$ is greater than 2 (WOOLDRIDGE, 2002).

Fixed Effects Model:

$$
Y_{i t}=\alpha+\mathrm{c}_{i}+\boldsymbol{X}_{i t} \boldsymbol{\beta}+\boldsymbol{\varepsilon}_{\mathbf{i t}}
$$

Transformation:

$$
\begin{aligned}
& Y_{i t}-Y_{m}=\left(\boldsymbol{X}_{\boldsymbol{i t}}-\boldsymbol{X} \boldsymbol{m}\right) \boldsymbol{\beta}+\left(\boldsymbol{\varepsilon}_{\mathbf{i t}}-\boldsymbol{\varepsilon}_{\mathbf{m}}\right) \\
& \mathrm{E}\left(\boldsymbol{\varepsilon}_{\mathbf{i t}} / \boldsymbol{X}_{\boldsymbol{i s}}, c i\right)=0 ; \text { for } \forall \mathrm{t} \neq \mathrm{s} \\
& \boldsymbol{\varepsilon}_{\mathbf{i t}} \sim \operatorname{IID}\left(0, \sigma^{2}\right)
\end{aligned}
$$

After estimating the three models, we shall carry out the necessary tests to elucidate the consistent estimators and, among those, which one is the most efficient. In this fashion, we use the Breusch-Pagan Test to check for the presence of idiosyncratic heterogeneity by analyzing the existence of self-correlation on the unobservable heterogeneity and the Hausman Test to check for the correlation between the idiosyncratic heterogeneity and the regressors (GREENE 2000; HAUSMAN, 1978).

\section{São Paulo economic voting model:}

The sample analyzed covers 625 of the 645 municipalities in the State of São Paulo, between 1994 and 2010. The dataset includes five types of variables: political, economic, fiscal, demographic and geographic, the last three being used as controls in the estimations. The basic equation to be estimated can be summarized as follows:

votes $_{i t}=\alpha+c_{i}+\beta_{1}$ encons $_{i t}+\beta_{2}$ control variables $_{i t}+\lambda$ geographic dummies $_{i t}+\varepsilon_{i t}$

where $i$ refers to the municipality, $t$ to the year, and $\alpha, c i$ and $\varepsilon_{\text {it }}$ are, the constant, municipal idiosyncratic heterogeneity and the error term, respectively; encons is the independent variable of interest and votes the dependent one. Votes indicates the percentage of valid votes (excluding blank and void votes) that the incumbent presidential candidate obtained in each municipality in São Paulo.

The incumbent candidates were the PSDB [the Brazilian Social Democracy Party] candidate, Fernando Henrique Cardoso, in 1994 and 1998, the PSDB candidate, José Serra, in 2002, the PT [the Worker's Party] candidate Luiz Inácio Lula da Silva in 2006 and the PT candidate, Dilma Rousseff in 2010. The encons regressor is the rate of growth 
in total energy consumption per capita in the municipality ${ }^{2}$, which, given our theoretical and methodological framework, is used as a measure of economic growth in the year of the presidential elections.

Table 1 - Elections results in Brazil and in São Paulo (1994 - 2010)

\begin{tabular}{|c|c|c|c|c|c|}
\hline \multirow[b]{2}{*}{ Candidate } & \multirow[b]{2}{*}{ Party } & \multicolumn{2}{|c|}{ Brazil } & \multicolumn{2}{|c|}{ Sao Paulo } \\
\hline & & Votes & $\%$ & Votes & $\%$ \\
\hline \multicolumn{6}{|c|}{1994 Election } \\
\hline Fernando Henrique Cardoso* & PSDB & $34,314,961$ & $54.2 \%$ & $8,679,287$ & $55.7 \%$ \\
\hline Luiz Inacio Lula da Silva & PT & $17,122,127$ & $27.1 \%$ & $4,205,530$ & $27.0 \%$ \\
\hline Eneas Ferreira Carneiro & PRONA & $4,671,457$ & $7.4 \%$ & $1,380,690$ & $8.9 \%$ \\
\hline Orestes Quercia & PMDB & $2,772,121$ & $4.4 \%$ & 895,318 & $5.8 \%$ \\
\hline Leonel Brizola & PDT & $2,015,836$ & $3.2 \%$ & 247,152 & $1.6 \%$ \\
\hline Esperidiao Amin & PPR & $1,739,894$ & $2.8 \%$ & 67,747 & $0.4 \%$ \\
\hline Others & - & 625,935 & $1.0 \%$ & 94,599 & $0.6 \%$ \\
\hline \multicolumn{6}{|c|}{1998 Election } \\
\hline Fernando Henrique Cardoso* & PSDB & $35,936,382$ & $53.1 \%$ & $9,736,728$ & $59.9 \%$ \\
\hline Luiz Inacio Lula da Silva & PT & $21,475,211$ & $31.7 \%$ & $4,688,677$ & $28.8 \%$ \\
\hline Ciro Gomes & PPS & $7,426,187$ & $11.0 \%$ & $1,208,718$ & $7.4 \%$ \\
\hline Eneas Carneiro & PRONA & $1,447,089$ & $2.1 \%$ & 389,592 & $2.4 \%$ \\
\hline Others & - & $1,437,434$ & $2.1 \%$ & 235,103 & $1.4 \%$ \\
\hline \multicolumn{6}{|c|}{2002 Election } \\
\hline Luiz Inacio Lula da Silva & PT & $39,455,233$ & $46.4 \%$ & $9,106,914$ & $46.1 \%$ \\
\hline Jose Serra* & PSDB & $19,705,445$ & $23.2 \%$ & $5,633,365$ & $28.5 \%$ \\
\hline Garotinho & PSB & $15,180,097$ & $17.9 \%$ & $2,781,712$ & $14.1 \%$ \\
\hline Ciro Gomes & PPS & $10,170,882$ & $12.0 \%$ & $2,087,617$ & $10.6 \%$ \\
\hline Others & - & 440,855 & $0.5 \%$ & 139,795 & $0.7 \%$ \\
\hline \multicolumn{6}{|c|}{2006 Election } \\
\hline Luiz Inacio Lula da Silva* & PT & $46,662,365$ & $48.6 \%$ & 8091867 & $36.8 \%$ \\
\hline Geraldo Alckmin & PSDB & $39,968,369$ & $41.6 \%$ & 11927802 & $54.2 \%$ \\
\hline Heloísa Helena & PSOL & $6,575,393$ & $6.8 \%$ & 1558639 & $7.1 \%$ \\
\hline Cristovam Buarque & PDT & $2,538,844$ & $2.6 \%$ & 385119 & $1.8 \%$ \\
\hline Others & - & 251,762 & $0.3 \%$ & 31,477 & $0.1 \%$ \\
\hline \multicolumn{6}{|c|}{2010 Election } \\
\hline Dilma Rousseff* & PT & $47,651,434$ & $47.0 \%$ & $8,740,949$ & $37.3 \%$ \\
\hline Jose Serra & PSDB & $33,132,283$ & $32.7 \%$ & $9,524,050$ & $40.7 \%$ \\
\hline Marina Silva & PV & $19,636,359$ & $19.4 \%$ & $4,865,828$ & $20.8 \%$ \\
\hline Plinio de Arruda Sampaio & PSOL & 886,816 & $0.9 \%$ & 239,173 & $1.0 \%$ \\
\hline Others & - & 150,682 & $0.1 \%$ & 56,299 & $0.2 \%$ \\
\hline
\end{tabular}

* The incumbents are the candidates with names in bold and shaded line

2. Total energy is the sum of all energy consumed by the municipality by residences, industry and commerce, in rural and urban areas and is measured in terms of megawatt hour (MWh). 
In Table 1, we present all main candidates of the Brazilian presidential elections from 1994 to 2010, with their respective votes both in Brazil and just in the state of São Paulo. As expected, the main candidates are those from the PSDB and the PT. In all elections, the PSDB candidates have performed better in São Paulo than in Brazil, whereas just the contrary happened to the PT.

\section{DATA}

The political variables were collected from the electoral base of the Brazilian Superior Electoral Court (TSE). We obtained information about all the 645 municipalities in São Paulo. However, as some municipalities were created after 1995, we decided to analyze just those that had been emancipated before 1994. Therefore, the sample analyzed comprised 625 municipalities in five subsequent electoral periods, thus constituting a balanced panel.

Table 2 - Description of the variables

\begin{tabular}{|c|c|}
\hline votes & $\begin{array}{l}\text { proportion of valid votes obtained by the incumbent in the munici- } \\
\text { pality }\end{array}$ \\
\hline encons & $\begin{array}{l}\text { rate of growth of total energy consumption per capita in the munici- } \\
\text { pality in the election year }\end{array}$ \\
\hline lencons & log of the total energy consumption of the municipality (MWh) \\
\hline fрop60 & proportion of the population over 60 in the municipality \\
\hline Irim & $\begin{array}{l}\text { log of the rate of infant mortality in the election year (per 1,000 live } \\
\text { births) }\end{array}$ \\
\hline Itotalexp & $\begin{array}{l}\text { log of total municipal expenses per capita in the election year, } \\
\text { measured in } R \$ 2010 \text { million }\end{array}$ \\
\hline linvestexp & $\begin{array}{l}\text { log of municipal expenditure on investments per capita in the } \\
\text { election year, measured in } \mathrm{R} \$ 2010 \text { million }\end{array}$ \\
\hline Istaffexp & $\begin{array}{l}\text { log of the municipal expenses on staff per capita in the election } \\
\text { year, measured in } \mathrm{R} \$ 2010 \text { million }\end{array}$ \\
\hline colmayor & $\begin{array}{l}\text { dummy relating to the party of the mayor that is a member of the } \\
\text { electoral coalition of the incumbent ( } 1 \text {-member; } 0 \text {-non-member) }\end{array}$ \\
\hline d94/98/02/06/10 & dummies for year \\
\hline drsi ... drsxvii & dummies for mesoregions (Regional Health Divisions) \\
\hline metrop & $\begin{array}{l}\text { municipality belonging to a metropolitan region in São Paulo (1-be- } \\
\text { longing; 0-not belonging) }\end{array}$ \\
\hline
\end{tabular}

The economic, demographic and fiscal variables were obtained from the State Data Analysis System Foundation (Seade). Among them we included the variable of interest, encons, the economic size of the municipality (measured by the log of the total energy consumption), the proportion of the population over 60 , the logarithm of the infant mortality rate, and finally the logarithms of total municipal expenses per capita, municipal spending on investments per capita and municipal expenses on staff costs per capita. 
In addition to the fiscal, demographic and economic information, we also controlled for the role played by the mayor, at the municipal level, in the election. To do so, we built a dummy variable that indicates whether the mayor belonged to a party of the incumbent coalition $^{3}$. We obtained data about the mayor's party affiliation from the results of the municipal elections immediately prior to the national election ${ }^{4}$.

Moreover, we also controlled for possible macro-economic shocks by creating dummies for year and also dummies for the state's meso-regions in order to control any regional factors that might interfere in the incumbent capability of obtaining votes in certain regions ${ }^{5}$. Finally, we created another dummy variable to indicate whether the municipality belongs to one of the three metropolitan regions in the State of São Paulo, namely: Greater São Paulo, Greater Campinas and the Baixada Santista. In Table 2 there is a description of the variables and in Table 3 their respective descriptive statistics.

Table 3 - Descriptive statistics

\begin{tabular}{lccccc}
\hline Continuous variables & Mean & Median & $\begin{array}{c}\text { Standard } \\
\text { deviation }\end{array}$ & Min. & Max. \\
\hline votes & 46.590 & 44.584 & 16.063 & 12.981 & 85.462 \\
encons & 0.034 & 0.030 & 0.099 & $-0,611$ & 3.029 \\
lencons & 9.870 & 9.547 & 1.790 & 5.609 & 16.960 \\
Fpop6 & 10.820 & 10.690 & 2.849 & 3.410 & 22.380 \\
Irim & 2.920 & 2.905 & 0.584 & 0.693 & 5.116 \\
Itotalexp & 7.350 & 7.323 & 0.417 & 6.014 & 9.766 \\
linvestexp & 5.160 & 5.122 & 0.737 & 2.254 & 8.142 \\
Istaffexp & 6.410 & 6.411 & 1.673 & 0.476 & 13.630 \\
\hline Dummy variables & Frequency & 0 & 1 & & \\
\hline colmayor & & 2008 & 1117 \\
Metrop & 2790 & 335 & & \\
\hline
\end{tabular}

\section{RESULTS}

In this section, we present the main results. First we examine the electoral performance of the incumbent in São Paulo by the POLS and after by RE and $F E$, all with robust standard errors. The coefficients of the variables that are constant over time are only shown in the estimations by POLS and RE, since one of the limitations of the FE estimation is that it is not suitable to analyze variables that are constant over time. In the first three columns of

3. The five coalitions are: 1994 - PSDB / PFL / PTB; 1998 - PSDB / PFL / PTB / PPB; 2002 - PSDB / PMDB; 2006 - PT, PRB, PCdoB; 2010 - PT, PMDB, PDT, PC do B, PSB, PR, PRB, PTN, PSC and PTC. The incumbent parties are, PSDB from 1994 to 2002, and PT in 2006 and 2010.

4. The data for the municipal elections of 1996, 2000, 2004 and 2008 were collected from the STE, while the data for 1992 were kindly provided by Sérgio Naruhiko Sakurai.

5. To analyze São Paulo's meso-regions we decided to use the administrative division adopted by the State Department of Health, which divides the State of São Paulo into 17 regional health departments. 
Table 4, we have included all the variables of the model, with the exception of the dummies for year and region. In the last columns, we present the estimated coefficients of the models including the dummies for year. The dummies for region were removed because they did not affect the coefficients of interest.

Table 4 - Proportion of votes for the incumbent

\begin{tabular}{|c|c|c|c|c|c|c|}
\hline votes & OLS & $\mathrm{RE}$ & $\mathrm{FE}$ & OLS_year & RE_year & FE_year \\
\hline \multirow[t]{2}{*}{$n \cos$} & $10.777 * *$ & $10.777^{* *}$ & $14.952 * * *$ & $4.010^{*}$ & $4.007^{*}$ & $4.357^{*}$ \\
\hline & 3.945 & 4.019 & 4.621 & 1.581 & 1.586 & 1.979 \\
\hline \multirow[t]{2}{*}{ lencons } & $-2.409 * * *$ & $-2.409 * * *$ & $-9.766 * * *$ & $-1.446 * * *$ & $-1.447 * * *$ & $-2.789 * *$ \\
\hline & 0.209 & 0.198 & 1.428 & 0.142 & 0.142 & 1.559 \\
\hline \multirow[t]{2}{*}{ fрop60 } & $-1.288^{* * *}$ & $-1.288^{* * *}$ & $-6.087 * * *$ & 0.095 & 0.096 & 0.046 \\
\hline & 0.108 & 0.116 & 0.362 & 0.082 & 0.082 & 0.375 \\
\hline \multirow[t]{2}{*}{ colmayor } & $6.720 * * *$ & $6.720 * * *$ & $6.187 * * *$ & $1.800 * * *$ & $1.805^{* * *}$ & $1.908 * * *$ \\
\hline & 0.561 & 0.556 & 0.586 & 0.409 & 0.409 & 0.458 \\
\hline \multirow[t]{2}{*}{ Irim } & $5.066 * * *$ & $5.066 * * *$ & $4.457 * * *$ & 0.157 & 0.155 & 0.169 \\
\hline & 0.487 & 0.518 & 0.619 & 0.327 & 0.327 & 0.424 \\
\hline \multirow[t]{2}{*}{ Itotalexp } & $-9.129 * * *$ & $-9.129 * * *$ & 2.703 & $-1.693^{*}$ & $-1.731^{*}$ & $-4.420 *$ \\
\hline & 0.909 & 0.966 & 2.063 & 0.702 & 0.701 & 1.753 \\
\hline \multirow[t]{2}{*}{ linvestexp } & $2.659 * * *$ & $2.659 * * *$ & -0.5 & 0.515 & 0.524 & $0.889 *$ \\
\hline & 0.464 & 0.437 & 0.538 & 0.325 & 0.325 & 0.426 \\
\hline \multirow[t]{2}{*}{ Istaffexp } & -0.385 & $-0.386^{*}$ & $3.730 * * *$ & 0.017 & 0.019 & 1.297 \\
\hline & 0.211 & 0.192 & 1.007 & 0.127 & 0.127 & 0.881 \\
\hline \multirow[t]{2}{*}{ metrop } & -1.121 & -1.122 & & $1.169 *$ & $1.176^{*}$ & \\
\hline & 0.992 & 0.993 & & 0.536 & 0.536 & \\
\hline \multirow[t]{2}{*}{ d1994 } & & & & $20.704 * * *$ & $20.692 * * *$ & $19.298 * * *$ \\
\hline & & & & 0.748 & 0.747 & 2.026 \\
\hline \multirow[t]{2}{*}{ d1998 } & & & & $25.724^{* * *}$ & $25.718 * * *$ & $24.847^{* * *}$ \\
\hline & & & & 0.642 & 0.642 & 1.388 \\
\hline \multirow[t]{2}{*}{ d2002 } & & & & $-4.023 * * *$ & $-4.03^{* * *}$ & $-4.846 * * *$ \\
\hline & & & & 0.602 & 0.602 & 1.143 \\
\hline \multirow[t]{2}{*}{ d2006 } & & & & $-2.743^{* * *}$ & $-2.745^{* * *}$ & $-3.065^{* * *}$ \\
\hline & & & & 0.349 & 0.348 & 0.56 \\
\hline \multirow[t]{2}{*}{ _cons } & $122.690 * * *$ & $122.69 * * *$ & $152.465^{* * *}$ & $60.221 * * *$ & $60.449 * * *$ & $84.873^{* * *}$ \\
\hline & 6.433 & 7.288 & 13.294 & 4.906 & 4.894 & 20.59 \\
\hline $\mathrm{N}$ & 2922 & 2922 & 2922 & 2922 & 2922 & 2922 \\
\hline
\end{tabular}

Note: ${ }^{*}<0,05 / * *<0,01 / * * *<0,001$

As expected, the Breusch-Pagan Test showed that the POLS method is unsuitable. Besides that, the Hausman Test rejected the hypothesis that there is no correlation between 
the idiosyncratic heterogeneity and the regressors. Therefore, the appropriate model that produces consistent and unbiased estimators is the fixed effects model.

The main conclusion we draw from the analysis is that the relationship between economic growth and the votes obtained by the incumbent in the municipality is both positive and significant. Independent of the model, all columns show that economic growth is an important determinant of the incumbent electoral support. These findings confirm the results presented by Fernandes and Fernandes (2017), that used data of real municipal GDP per capita for a small period of time. The result is connected with the theoretical expectations due to the fact that, from the population's point of view, the responsibility for the economic performance of the country lies heavily on the Brazilian presidents. Besides, our results indicate that even the local economic perception affects how people evaluate the political national scenario ${ }^{6}$.

The three first columns of coefficients in Table 4 indicate that growth in energy consumption per capita in the municipality (encons) bears a positive and significant relationship with the percentage of votes obtained by the incumbent. The coefficients of the estimates by FE are greater and have the same significance as the coefficients of the estimates by POLS and by $R E$, indicating that economic voting is present in Brazilian presidential elections at the municipal level in the State of São Paulo. Column 4 indicates that an increase of 10 percentage points on the growth of total energy consumption per capita increases the incumbent electoral support in 1.49 percentage points.

In addition to this strong evidence of the relationship between growth in energy consumption per capita and the vote obtained by the presidential incumbent, the first three columns in Table 4 also have a series of other interesting results that are worth discussing.

Among them, we would draw attention to the fact that in all the models the coefficients of the level of energy consumption and the proportion of the elderly population were negative and significant, suggesting that the smaller the local economy of the municipality, the greater the tendency of votes going for the incumbent.

These findings confirm the argument made by Ribeiro (2014), Canêdo-Pinheiro (2015), and Zucco $(2008 ; 2010)$ that there is a strong manifestation of "governism" in Brazilian elections. On one hand, these results should be taken with caution as we are not analyzing the role of the conditional cash transfer programs, which was the main preoccupation the literature. On the other hand, there is strong evidence that even in São Paulo there is a tendency for municipalities with smaller economies to give more support to the incumbent.

Another result that appears to go in the same direction is the coefficients of the infant mortality rate in the election year, which had positive and significant correlations with electoral performance. To understand this finding, it is important to consider that local, state and federal levels share responsibilities as providers of health care in Brazil. Consequently, the interpretation we place on this result is that the rate of infant mortality not only captures the performance of the government in the health area, which has blurred shared responsibilities among federal members, but it also is an important indicator that municipalities which

6. Further research should test whether the effects of local economic growth on incumbent electoral performance are valid at both mayors and governors' elections, besides presidents (see FERNANDES; FERNANDES, 2014). 
suffer from poorer socio-economic conditions, as reflected in a higher mortality rate, tend to have a more incumbent-oriented electorate.

Zucco (2008) shows that since 1994 all incumbents have done better on impoverished areas, as the negative result between incumbent performance and the municipal human developed index (HDI) indicates. The author also indicated that all the parties that gained power after the redemocratization process - chronologically, the PMDB, PSDB and PT - were at first supported by larger cities and more developed areas. After the party became the chief of the federal executive power, its electorate gradually rearranged toward the less developed areas - the so called grotões. Zucco's (2008) and our results indicate that independently of what the party stands for, the federal government tends to have a better electoral performance in the poorest regions of the country, while the opposite holds for the main opposition parties ${ }^{7}$.

It is worth remembering that the poorest municipalities tend to have a greater percentage of revenue coming from federal coffers, hence the voters in these locations might be more sensitive to the incumbent. This way, the federal government has a strong hand in the countryside, since it is the main entity with resources and capabilities do undertake the task of large scale poverty alleviation and infra-structure investments. Furthermore, in the municipalities we analyzed, the elderly population might reflect an income potential that is associated with retirement. On the one hand, populations with an older age structure are richer, which makes it clearer that the weight of economic growth is a contrary factor. However, it must be emphasized that the amounts paid in pensions are defined by the federal government and the period analyzed was characterized by various attempts of reforming the social security system. In order to reduce the heavy deficit of the sector, the proposed reforms always consisted in reducing the benefits of the general population. Therefore, the retired people group in the elderly population can be seen as a segment that is contrary to the Brazilian incumbent. These results indicate an interesting field for future research ${ }^{8}$.

There are no studies in the literature on age and voting that found a similar result about the anti-incumbency bias of the older population, neither in Brazil nor abroad. The general debate since Cumming and Henry (1961) is on the disengagement theory: the elderly gradually become less involved in society. As indicated by Glenn and Grimes (1968) if the theory is correct, one of its manifestations would be a decline in political interest and the participation of the elderly as individuals would become less attuned to some important societal issues. Hence, it is expected that the older-aged group have a substantially lower turnout than middle-aged or younger groups. Bhatti and Hansen (2012) have found

7. It is worth noting that the 'governism' argument highlights that incumbents tend to electorally do better in the most impoverished regions of the Northeast and North of Brazil. Our results are circumscribed to the richest state of the country, indicating that this argument operates within the different regions across all the country, as São Paulo would be the worst case scenario for governism to work as an electoral pattern.

8. An important methodological question is that as we are dealing with aggregate data, we are not able to say which type of specific individual is voting for or against the incumbent. All the relations that we found are about the municipality aggregate measures. So, we cannot affirmatively say that elder people are more prone to be against the incumbent. What we found is that the municipalities with a bigger proportion of elder people are less oriented to vote with the incumbent. Hence, we can just speculate about the mechanisms that explain our results. By itself, the aggregate results do not make it possible to assert on individuals - a typical case of ecological fallacy (KRAMER, 1983). 
a similar result analyzing individual level data on Danish elections: older retired people tend to participate less frequently on elections. They explain this pattern with a different set of rationales. Besides health motives, retired people tend to feel less mobilized to vote due to the disruption of social ties and less contact with other people that could encourage political participation. Unfortunately, we could not find any discussion about the political participation of Brazilian elders ${ }^{9}$.

The dummy variable relating to the incumbent candidate being allied to the mayor shows the importance of the role of the mayor in the national elections. The relation is positively and robustly significant in all models. Moreover, it has a strong partial effect, since its coefficient indicates that, on average, those mayors who are members of the electoral coalition increase the vote for the incumbent by around 6.1 percentage points. The results indicate that the mayors are one of the most important electoral brokers of incumbent presidents at the local level. An argument made by the former governor of São Paulo, Orestes Quércia at an editorial note on the front page of a local newspaper in the year of 1984 during the democratization process - highlights this rationale:

In political practice, municipal authorities are fundamental to the parties. They are ultimately responsible for the election of governors, state deputies, federal deputies, and senators. Mayors, deputy mayors and city councillors are decisive electoral canvassers. It is, therefore, natural for these politicians to act as intermediaries between voters and their representatives (QUÉRCIA, $1984)^{10}$.

These positive results of the alliance between presidents and mayors had already been perceived by Ames (1994) whoshowed that the presidential candidates of the 1989 elections did significantly better in municipalities where the mayor represented their party. Actually, the results of Ames's study are more generalizable than ours, due to the fact that the role of mayors is not just related to retrospective alliances, as it is our case, but also to prospective alliances between mayors and the presidential candidates.

These special relations between mayors and presidents in Brazilian presidential elections are not a specific trait of Brazilian politics. The literature is full of examples of how local political organizations deliver blocks of votes to candidates that the local leadership prefer. Buitrago and Davila (1990) studied this relation in Colombia, and Coppedge (1993) presents evidence in Mexico and Venezuela. Chubb (1982) indicates how the Christian Democratic power in the major southern cities of Italy had been based on the control of the municipalities, before the collapse of the Italian party system.

9. Goerres (2007), on the other hand, presents different rationales of reasons why elder people could vote more frequently than young cohorts, such as sense of duty, duration of residence, political interest and mainly social norms that generate a civic duty to vote. Both Goerres (2007) and Gleen and Grimes (1968) present data from comparative country analysis and from the US, respectively, that diverge from the disengagement theory. In both studies, older-aged groups participate less than middle-aged ones, but more than youngers.

10. "Na prática política, as autoridades municipais são fundamentais aos partidos. Elas, em última instância, são as responsáveis pela eleição de governadores, deputados estaduais, deputados federais e senadores. Os prefeitos, vice-prefeitos e vereadores são cabos eleitorais de importância decisiva. Nada mais natural, portanto, que esses políticos funcionem como intermediários entre os eleitores e seus representantes." (QUÉRCIA, 1984). 
Ames (1994) proposes that endorsement seeking by Brazilian mayors is related to the fact that strong local machines have the tools to influence the choice of voters. As an anecdotal case, Ames highlights the failure of Leonel Brizola to get votes in Sao Paulo. Despite the fact that he had strong political support in both Rio Grande do Sul and Rio de Janeiro, he was unable to get more than 1,5\% of votes in the state of São Paulo. The failure of Brizola highlights the importance of local organizations, as his party - the PDT - controlled just few municipalities in the state of São Paulo ${ }^{11}$.

On the other hand, Zucco (2008) tested whether political alliances between the federal government and both governor and mayors in the 2006 presidential elections improved the performance of the incumbent, also using municipal level data. His results were on the opposite direction than ours. He found that alliance with governors and mayors did not improve the electoral performance of the incumbent candidate at presidential elections. Actually, they reduced his overall performance. He tested both whether governor and mayor were from the PT - Lula was the 2006 running president - or whether they were elected by a coalition of parties that included the PT. He explained this odd result with the following argument: "[...] the negative coefficients on the political variables simply reflect the fact that part of his old voting base abandoned Lula" (ZUCCO, 2008, p. 40).

With regard to the municipal fiscal variables, total municipal expenses per capita, municipal spending on investments per capita and municipal expenses on staff costs per capita, only the latter was significant in the FE model. However, its sign, like the sign of the other expenses, changed with the different models, indicating that the relationship between municipal expenses and a pro-incumbent electorate in presidential elections is not clear. Anyway, it is important to take into account the fact that municipal spending is directly related to those services provided by the local government. With respect to political attribution, this result suggests that the local electorate seems to identify who is responsible for the menu of public policies. Growth and the size of the local economy are factors that are related to the federal government. However, local education or infrastructure is more connected to local politicians. As a result, the share of votes of the local incumbent should not be sensitive to the municipal expenditures.

To analyze those relations in greater depth we decided to retest the estimates by introducing dummies for year among the regressors. The results of this analysis, shown at the three last columns of Table 4, were surprising, but they kept their sign and the statistical significance of the main regressor of interest, in addition to also maintaining the significant effects of the mayors and the economic potential of the municipality. The coefficients of the rate of growth in energy consumption per capita were positive and significant, reaffirming the evidence of the presence of economic voting in presidential elections in municipalities in São Paulo. The level of energy consumption also remained negative and statistically significant, reflecting the anti-incumbent nature of richer cities. On the other hand, the dummy indicator, whether the municipality belongs to a metropolitan region, which was insignificant in the first two models, is now positive related to voting for the incumbent. This finding contradicts the anti-incumbent bias of more developed regions of the state. In the same direction, the

11. There is strong evidence for the failure of Brizola in the state of São Paulo in the 1989 election. Ames (1994) had shown that Brizola had support in Sao Paulo only in the municipalities closest to the border with the state of Rio de Janeiro. Electoral support to Brizola fell rapidly, as the analysis moves away from that border. 
positive coefficient of infant mortality rate loses significance and the signal is inverted, while insignificant, for the fraction of elderly people in the municipality.

As expected, all the dummies for year were significant, while with regard to the variables of municipal expenses, only total municipal expenses were significant in the three models. However, unlike what we had been expecting, its signal was negative, indicating that voters do not reward the presidential incumbent when there is greater spending by the municipality. Expenses with personnel, on the other hand, were not significant in any model and investments were significant only in the fixed effects model, where it had a positive sign.

\section{ROBUSTNESS CHECKS}

In this section we verify if the growth in energy consumption per capita is a good proxy of the municipalities' economic performance. In order to do that, we remake previous analyses using the growth rate of real municipal GDP, the most appropriate way to measure economic performance. Unfortunately, we only have data for the years 2002 and 2006.

Table 5 - Robustness check

\begin{tabular}{|c|c|c|c|}
\hline votes & OLS & RE & FE \\
\hline \multirow[t]{2}{*}{ encos } & 3.529 & 3.529 & 6.729 \\
\hline & 2.209 & 2.247 & 4.756 \\
\hline \multirow[t]{2}{*}{ gdpgr } & $3.877^{*}$ & $3.877 *$ & $8.125^{* *}$ \\
\hline & 1.727 & 1.741 & 3.086 \\
\hline \multirow[t]{2}{*}{ lencons } & $-1.556 * * *$ & $-1.556 * * *$ & -4.421 \\
\hline & 0.238 & 0.166 & 4.417 \\
\hline \multirow[t]{2}{*}{ fрop60 } & $-0.249 *$ & $-0.249 * *$ & 0.380 \\
\hline & 0.124 & 0.088 & 1.163 \\
\hline \multirow[t]{2}{*}{ colmayor } & 0.967 & 0.967 & 1.361 \\
\hline & 0.601 & 0.606 & 1.144 \\
\hline \multirow[t]{2}{*}{ Irim } & -0.211 & -0.211 & -1.367 \\
\hline & 0.519 & 0.493 & 1.012 \\
\hline \multirow[t]{2}{*}{ Itotalexp } & 0.555 & 0.555 & 10.610 \\
\hline & 1.232 & 0.869 & 7.090 \\
\hline \multirow[t]{2}{*}{ linvestexp } & 0.779 & 0.779 & 1.712 \\
\hline & 0.573 & 0.502 & 1.274 \\
\hline \multirow[t]{2}{*}{ Istaffexp } & -0.048 & -0.048 & 1.889 \\
\hline & 0.210 & 0.136 & 1.859 \\
\hline \multirow[t]{2}{*}{ metrop } & 2.162 & $2.162 * * *$ & - \\
\hline & 1.154 & 0.547 & - \\
\hline \multirow[t]{2}{*}{ _cons } & $45.085^{* * *}$ & $45.085^{* * *}$ & -21.078 \\
\hline & 8.771 & 5.666 & 48.884 \\
\hline $\mathrm{N}$ & 1160 & 1160 & 1160 \\
\hline
\end{tabular}

Note: ${ }^{*}<0,05 / * *<0,01 / * * *<0,001$ 
With a view to do this, in Table 5 we reran the analyses made in Table 4 with the inclusion of the new variable: the growth rate of real municipal GDP (gdpgr). If the growth in energy consumption per capita is a good proxy, it is expected that its effect disappears once the true variable is included in this model ${ }^{12}$. And this is exactly the result that we have found, demonstrating that the findings of the previous section are robust and significant and that the rate of growth in total energy consumption per capita in the municipality is a good proxy for municipal economic growth in the election year. Furthermore, the only variable that is significant and positively related to the proportion of votes obtained by the incumbent in the most appropriate model, the fixed effects, is the variable of interest gdpgr. On the other hand, in the other models (POLS and RE), both the level of energy consumption and the proportion of the elderly population were negative and significant in relation to the proportion of valid votes obtained by the incumbent.

\section{CONCLUSIONS}

The purpose of this paper was to analyze whether the economic growth has an effect on the proportion of votes obtained by the incumbent in a sample of the population of the municipalities of the state of São Paulo for the presidential elections of 1994, 1998, 2002, 2006 and 2010. As a measure for economic growth, the rate of increase in energy consumption per capita was used. Other variables of interest were also analyzed, particularly those relating to the role of the mayor as a member of the incumbent's party coalition, municipal expenses, the elderly fraction of the population, the level of total energy consumption (which served as control for the level of income) and the rate of infant mortality.

The main results confirm that there is strong evidence of a relationship between economic growth and the votes obtained by the presidential incumbent in all the models we estimated. We also saw that the level of energy consumption and the proportion of elders was negative and significant, suggesting that the greater the economic potential of the municipalities, the greater the tendency to vote against the incumbent.

Another important finding was the role that mayors play within the incumbent's electoral coalition when it comes to transfer votes that are favorable to the party in power. The relationship between the presence of an allied mayor and the votes transfered to the incumbent in all the models proved to be statistically significant and with a fairly relevant positive effect. Also, we observed that a higher infant mortality rate tends to favor the incumbent, which seems to indicate that worse socio-economic conditions tend to result in a more government-oriented electorate.

We reaffirmed those results by modeling the same variables using additional dummies for years as control for external shocks and confirmed the main results, except for the effects of municipal expenses, which presented very unstable coefficients throughout the whole of the modeling exercise.

12. Wooldridge (2002) presents two formal requirements for a proxy variable. The first, and most important, is that the proxy variable $z$ should be redundant in a structural equation. In other words, a good proxy must be irrelevant for explaining the dependent variable $y$ once controlled for the true explanatory factor $x$. The second requirement is that the correlation between the omitted variable $x$ and each other regressor be zero once we partial out $z$. 
Finally, some important topics were highlighted and must be addressed by future research. First, the fact that the proportion of elderly citizens in a municipality demonstrated to be related to lower incumbent support must be analyzed with care because, as we are dealing with aggregate data, we cannot affirm with certainty that the elderly people are opposition prone or that other segments of the population are activated against the incumbent when there are more elderly people in a town. Second, the positive impact of infant mortality rate in the election year can be an indicator that municipalities suffering from poorer socio-economic conditions tend to have a more government-oriented electorate. We claim that other research strategies can be used to illuminate whether this hypothesis is true or not. And, finally, the role played by the mayors in an electoral coalition must be studied so that we can improve our understanding of the relations between national and local politics in Brazil.

In short, this paper has produced evidence that is favorable to the hypothesis of economic voting in presidential elections in the State of São Paulo by indicating a positive and significant impact between growth in energy consumption per capita and the votes obtained by the presidential incumbent, while at the same time indicating that the mayor plays a key role in these same national elections.

\section{REFERENCES}

AMES, B. The reverse coattails effect: Local party organization in the 1989 Brazilian presidential election. American Political Science Review, v. 88, n. 1, p. 95-111, 1994.

ANDERSON, C. D.; MORGAN, J. Economic Voting and Incumbent Mayoral Elections in Canada: 1997:2010. 2011. Paper prepared for presentation at the Annual Meetings of the Canadian Political Science Association, Waterloo, CA, 2011. Available at: <https://www. cpsa-acsp.ca/papers-2011/Anderson.pdf>.

BALBACHEVSKY, E. Identidade Partidária e Instituições Políticas no Brasil. Revista de Cultura e Política Lua Nova, São Paulo, n. 26. 1992.

BERELSON, B.; LAZARSFELD, P.; MACPHEE, W. Voting: a study of opinion formation in a presidential campaign. Chicago: Univ. of Chicago Press. 1954.

BHATTI, Y.; HANSEN, K. M. Retiring from voting: Turnout among senior voters. Journal of Elections, Public Opinion \& Parties, v. 22, n. 4, p. 479-500, 2012.

BRENDER, A. The effect of fiscal performance on local government election results in Israel: 1989-1998. Journal of Public Economics, v. 87, n. 9-10, p. 2187-2205, 2003.

BUITRAGO, F; DAVILA, A. Clientelismo: El Sistema Político y Su Expresión Regional. 1st ed., Bogotá: Instituto de Estudios Políticos y Relaciones Internacionales. 1990.

CAMERON, A. C.; TRAVEDI, P. K. Microeconometrics: methods and applications. Cambridge Univ. Press, New York, 2005.

CAMPBELL, A. et al. The American Voter. Nova lorque: Wiley Press. 1960

CANÊDO-PINHEIRO, Mauricio. Bolsa Família ou desempenho da economia? Determinantes da reeleição de Lula em 2006. Economia Aplicada, v. 19, n. 1, p. 31-61, 2015. 
CARREIRÃO, Y. S. A decisão do voto nas eleições presidenciais brasileiras. Florianópolis. Ed. UFSC/FGV. 2002.

CARREIRÃO, Y. S.; KINZO, M. Partidos Políticos, preferência partidária e decisão eleitoral no Brasil (1989-2002). Dados - Rev. de Ciências Sociais. v. 47, n. 1, 2004.

CASTRO, M. M. Determinantes do Comportamento Eleitoral: a centralidade da sofisticação política. 1994. Tese (Doutorado em Ciência Política) - luperj. Rio de Janeiro, 1994.

CHUBB, J. Patronage, Power, and Poverty in Southern Italy. Cambridge: Cambridge University Press. 1982.

CINTRA, A. O. Partidos Políticos em Belo Horizonte: Um Estudo do Eleitorado. Dados - Rev. de Ciências Sociais, Rio de Janeiro, n. 5. 1968.

COPPEDGE, M. Parties and Society in Mexico and Venezuela: Why Competition Matters. Comparative Politics. v. 25, p. 253-74, 1993.

CUKIERMAN, A.; MELTZER, A. A political theory of government debt and deficits in a neo-Ricardian framework. The American Economic Review, v. 79, n. 4, p. 713-732, 1989.

CUMMING, E.; HENRY, W. E. Growing old, the process of disengagement. Basic Books: New York, 1961.

DOWNS, A. An Economic Theory of Democracy. New York: Harper, 1957.

DRAZEN, A.; ESLAVA, M. Electoral manipulation via voter-friendly spending: theory and evidence. Journal of Development Economics, v. 92, n. 1, p. 39-52, 2010.

DUCH, R.; STEVENSON, R. T. The Economic Vote: How Political and Economic Institutions Condition Election Results (Political Economy of Institutions and Decisions). New York: Cambridge Univ. Press, 2008.

ELINDER, M. Local economies and general elections: The influence of municipal and regional economic conditions on voting in Sweden 1985-2002. European Journal of Political Economy, v. 26, n. 2, p. 279-292, 2010.

FAIR, R. C. The Effect of Economic Events on Votes for President: 1992 Update. Political Behavior, v.18, n. 2, p. 119-139, 1996a.

. Econometrics and Presidential Elections. Journal of Economic Perspectives. v. 10, n. 3, 1996b.

. The Effect of Economic Events on Votes for President. Review of Economics and Statistics, v. 60, 1978.

FERNANDES, I; FERNANDES, G. The importance of local economic growth on the elections of Brazilian chief executives of governments. Revista de Administração Pública - RAP. v. 51, n. 4. 2017.

Economic voting at Brazilians elections: when local power plays the most important role. 2014. Paper prepared for presentation at the 72th Annual Midwest Political Science Association Conference. Chicago, Illinois, United States. 2014.

FERREIRA, O. A Crise de Poder do Sistema e as Eleições Paulistas de 1962. Rev. Brasileira de Estudos Políticos, n. 16, 1962. 
FERREIRA, O. Comportamento Eleitoral em São Paulo. Rev. Brasileira de Estudos Políticos. n. 8. 1960.

FIORINA, M. Retrospective voting in American national elections. Nova Heaven. Yale Univ. Press. 1981.

FLEISHER, D. Os partidos políticos no Brasil. v. 1. Brasília: Ed Univ. de Brasília, 1981.

GLENN, N. D.; GRIMES, M. Aging, voting, and political interest. American Sociological Review, v. 33, n. 4, p. 563-575, 1968.

GOERRES, A. Why are older people more likely to vote? The impact of ageing on electoral turnout in Europe. The British Journal of Politics \& International Relations, v. 9, n. 1, p. 90-121, 2007.

GREENE, W. Econometric Analysis. 4. ed., Prentice Hall. 2000.

HAUSMAN, J. Specification tests in econometrics. Econometrica, v. 46, n. 6, 1978.

HOLZHACKER, D.; BALBACHEVSKY, E. Classe, ideologia e política: uma interpretação dos resultados das eleições de 2002 e 2006. Opinião Pública, v. 13, n. 2, 2007.

HSIAO, C. Analysis of Panel Data. Cambridge: Ed. Cambridge Univ. Press, 1986.

HUNTER, W.; POWER, T. Rewarding Lula: Executive Power, Social Policy and the Brazilian Elections of 2006. Latin American Politics \& Society, v. 48, n. 1, 2007.

KINZO, M. Os partidos políticos no eleitorado: percepções públicas e laços partidários no Brasil. Rev. Brasileira de Ciências Sociais, v. 20, n. 7, 2005.

KRAMER, G H. The ecological fallacy revisited: Aggregate-versus individual-level findings on economics and elections, and sociotropic voting. American Political Science Review, v. 77, p. 92-111, 1983.

. Short-Term Fluctations in U.S. Voting Behavior, 1896-1964. American Political Science Review, v. 65, p. 131-143, 1971.

LAMONIER, B. Voto de Desconfiança. Rio de Janeiro: Vozes, 1980.

LAZARSFELD, P.; BERELSON, B.; GAUDET, H. The People's Choice: how the votes makes up in a presidential campaign. New York: Columbia Univ. Press, 1944.

LIMONGI, F.; GUARNIERI, F. Competição partidária e voto nas eleições presidenciais no Brasil. Opinião Pública, v. 21, n. 1, 2015.

A base e os partidos. Novos Estudos Cebrap, n. 99, 2014.

MAGALHÃES, A.; SILVA, M. E. A.; DIAS, F. M. Eleição de Dilma ou segunda reeleição de Lula? Uma análise espacial do pleito de 2010. Opinião Pública, v. 21, n. 3, 2015.

MARTINS, R.; VEIGA, F. J. Economic voting in Portuguese municipal elections. Public Choice, v. 155, n. 3-4, p. 317-334, 2013.

MARZAGÃO, T. A dimensão geográfica das eleições brasileiras. Opinião Pública, v. 19, n. 2, 2013.

NICOLAU, J.; PEIXOTO, V. As Bases Municipais da Votação de Lula em 2006. In: REIS VELLOSO, J. P. (coord.). Quem elegeu Lula? As forças e fatores políticos que levaram aos 
60 milhões de votos. Rio de Janeiro: INAE, 2007. [Cadernos do Fórum Nacional, n. 6 - I Fórum Internet].

OLIVER, J.; HA, S. Vote choice in suburban elections. American Political Science Review, v. 101, n. 3, p. 393-408, 2007.

PATTIE, C.; JOHNSTON, R. A low turnout landslide: Abstention at the British general election of 1997. Political Studies, v. 49, n. 2, p. 286-305, 2001.

PEREIRA, A. et al. A eleição de Dilma em 2010 e seus determinantes: evidências empíricas do Programa Bolsa Família. Análise Econômica, n. 64, 2015.

PIMENTEL JR., J. T. P. Razão e Emoção no Voto: o caso da eleição presidencial de 2006. 2007. Dissertação (Mestrado em Ciência Política) - Faculdade de Filosofia, Letras e Ciências Humanas, Universidade de São Paulo, São Paulo, 2007.

POWELL JR, G. B.; WHITTEN, G. D. A Cross-National Analysis of Economic Voting: Taking Account of the Political Context. American Journal of Political Science, v. 37, n. 2, p. 391-414, 1993.

QUÉRCIA, O. Municípios, Avante!. Jornal do Interior. São Paulo; mar 1984, ano V, p. 01. Available at: <http://ninive.selfip.com:8080/quercia/bitstream/handle/123456789/787/ CXA007_Jornal-do-Interior-Sao-Paulo-mar-84-p1-001. pdf?sequence=2\&isAllowed=y $>$.

REIS, F. W. Os Partidos e o Regime. A lógica do processo eleitoral brasileiro. São Paulo: Símbolo, 1978.

RENNÓ, L; CABELLO, A. As bases do lulismo: a volta do personalismo, realinhamento ideológico ou não alinhamento?. Revista Brasileira de Ciências Sociais, v. 25, n. 74, 2010.

RIBEIRO, R. M. Decadência longe do poder: refundação e crise do PFL. Revista de Sociologia e Política, v. 22, n. 49, 2014.

SAKURAI, S.; MENEZES, N. Fiscal policy and reelection in Brazilian municipalities. Public Choice, v. 137, n. 1-2, p. 301-314, 2008.

SIMÃO, A. O voto operário em São Paulo. Rev. Brasileira de Estudos Políticos. Belo Horizone, n. 1, 1956.

SIMONI, S. Política distributiva e competição presidencial no Brasil: Programa Bolsa-Família e a tese do realinhamento eleitoral. 2017. Tese (Doutorado em Ciência Política) - Faculdade de Filosofia, Letras e Ciências Humanas, Universidade de São Paulo, São Paulo, 2017.

SINGER, A. Os sentidos do Iulismo. São Paulo: Companhia das Letras, 2012. 2009.

. As raízes sociais do lulismo. Caderno de Novos Estudos Cebrap, São Paulo, n. 85,

Esquerda e Direita no Eleitorado Brasileiro. São Paulo: Edusp. 1999.

SOARES, G. A. As Bases Ideológicas do Lacerdismo. Revista Civilização Brasileira, v. 1, n.4, Rio de Janeiro, 1965.

SOARES, G. A; TERRON, S. Dois Lulas: a geografia eleitoral da reeleição (explorando conceitos, métodos e técnicas de análise geoespacial). Opinião Pública, v. 14, n. 2, p. 269-301, 2008. 
STIGLER, G. J. General Economic Conditions and National Elections. American Economic Review, v. 63, p. 160-164, 1973.

VEIGA, L.; VEIGA, F. Does opportunism pay off? Economics Letters, v. 96, n. 2, p. 177-182, 2007.

VIRMANI, A. Economic Growth, Governance and Voting Behaviour: an application to Indian Elections. New Delhi: Indian Council for Research on International Economic Relations - ICRIER, jul., 2004. [Working Paper n. 138].

WOOLDRIDGE, J. M. Econometric Analysis of Cross Section and Panel Data. MIT Press: Cambridge, 2002, 752p.

ZUCCO, C. When payouts pay off: Conditional cash transfers and voting behavior in Brazil 2002-10. American Journal of Political Science, v. 57, n. 4, p. 810-822, 2013.

Poor Voters vs. Poor Places: Persisting patterns in presidential elections in Brazil. Prepared for the Center for Metropolitan Studies Seminar "Metropolis and Inequalities", São Paulo, March 24-26, 2010.

. The President's Nova Constituency: Lula and the Pragmatic Vote in Brazil's 2006 Presidential Elections. Journal of Latin American Studies, v. 40, n.1, 2008.

ZUCCO, C.; POWER, T. Bolsa Família and the shift in Lula's Electoral Base, 2002-2006: A reply to Bohn. Latin American Research Review, v. 48, n.2, p. 3-24, 2013.

Submission date: 12/06/2016.

Approval date: 11/27/2017.

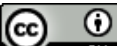

Creative Commons Atribuição 4.0 Internacional

Note: you can find this paper in Portuguese at http://www.revistaoes.ufba.br. 